\title{
Facial and bulbar muscle atrophy in acetylcholine receptor antibody-positive myasthenia gravis
}

Atrofia de musculatura facial e bulbar em miastenia gravis com presença do anticorpo Anti-AChR Ronnyson Susano Grativvol', André Macedo Serafim da Silva', Bruno Fukelmann Guedes ${ }^{1}$, Eduardo de Paula Estephan', Rodrigo de Holanda Mendonça ${ }^{1}$, Antônio Alberto Zambon'1, Carlos Otto Heise', Edmar Zanoteli'

A 62-year-old man presented with seven years of progressive dysphagia, dysphonia and difficulty in closing both eyes. His examination showed weakness and atrophy of facial and bulbar muscles without ocular involvement (Figure A, B and C). Single-fiber electromyography revealed increased jitter (Figure D). To evaluate for concurrent myopathy, a muscle biopsy was performed and showed angulated atrophic type II fibers, a particular finding described in patients with myasthenia gravis ${ }^{1,2}$ (Figure E). Acetylcholine receptor antibody was positive $(2.2 \mathrm{nmol} / \mathrm{L})$. Pronounced facial and tongue atrophy is uncommon in myasthenia gravis and usually associated with the muscle-specific receptor tyrosine kinase antibody, which was negative in this patient ${ }^{3,4}$.
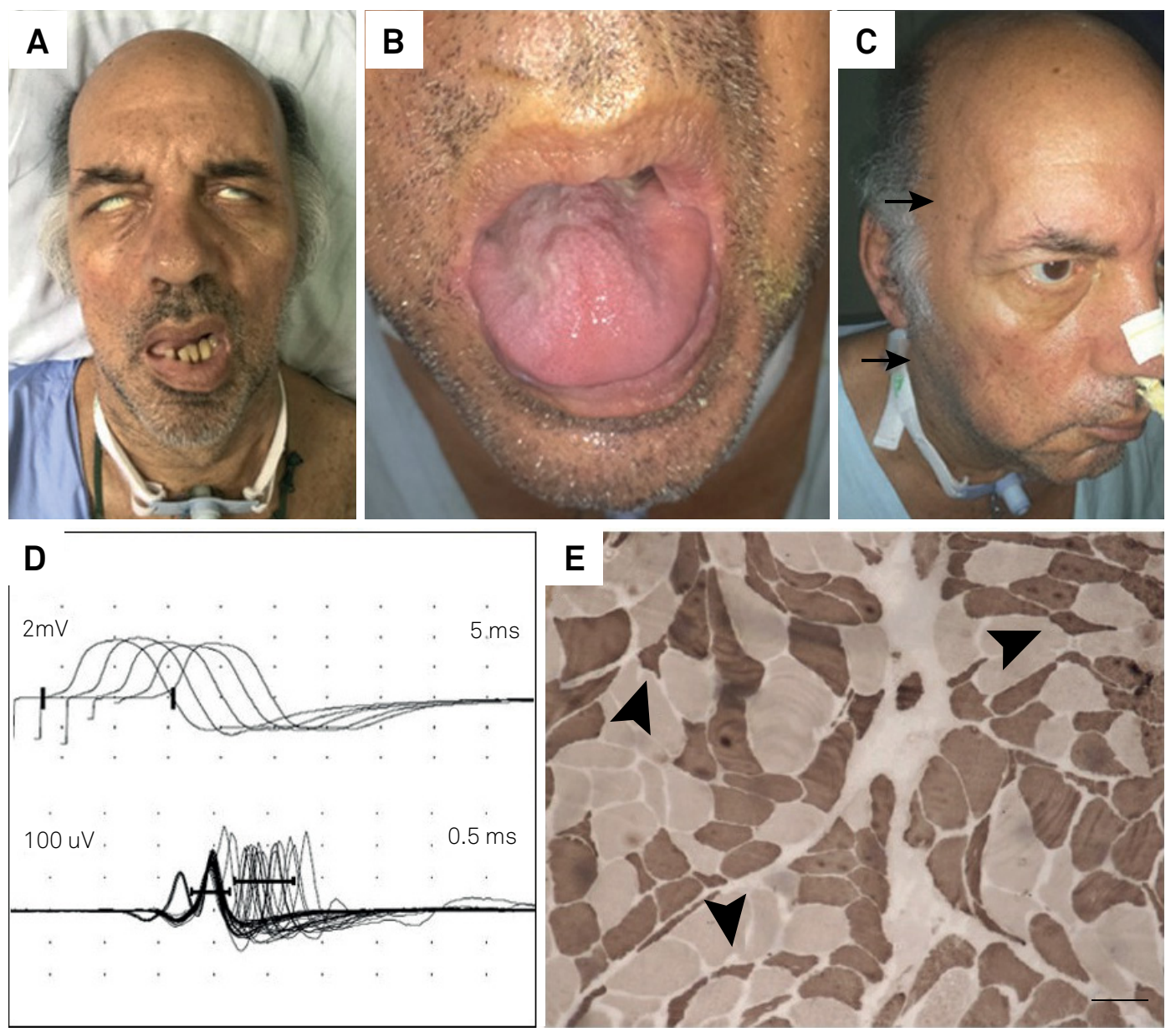

Figure. Clinical, electrophysiological and left biceps brachii muscle biopsy findings. Bilateral facial weakness, Bell's sign (A) and atrophy of the tongue (B), temporal and masseter muscles (arrows) (C). Repetitive stimulation was unremarkable (upper image) and the single-fiber electromyography demonstrated increased jitter (bottom image) (D). Muscle ATPase (pH 9.4) stain revealed angulated fiber II atrophy (arrowhead) (E). Bar $=100 \mu \mathrm{m}$.

${ }^{1}$ Universidade de São Paulo, Faculdade de Medicina, Departamento de Neurologia, São Paulo, Brasil.

Correspondence: Edmar Zanoteli;Av. Dr. Enéas de Carvalho Aguiar, 255; 50 andar / sala 5084; 05403-900 São Paulo SP, Brasil; E-mail: zanoteli@terra.com.br Conflict of interest: There is no conflict of interest to declare.

Received 26 July 2016; Accepted 31 October 2016. 


\section{References}

1. Oosterhuis $\mathrm{H}$, Bethlem J. Neurogenic muscle involvement in myasthenia gravis. A clinical and histopathological study. J Neurol Neurosurg Psychiatry. 1973;36(2):244-54. https://doi.org/10.1136/jnnp.36.2.244

2. Werneck LC. The muscle lesion in myasthenia gravis: a study of 17 cases with muscle histochemistry.

Arq Neuropsiquiatr. 1982;40(1):67-76.

https://doi.org/10.1590/S0004-282X1982000100007
3. Farrugia ME, Robson MD, Clover L, Anslow P, Newsom-Davis J, Kennett $\mathrm{R}$ et al. MRI and clinical studies of facial and bulbar muscle involvement in MuSK antibody-associated myasthenia gravis. Brain. 2006;129:1481-92. https://doi.org/10.1093/brain/awl095

4. Nikolić AV, Bačić GG, Daković MŽ, Lavrnić SĐ, Rakočević Stojanović VM Basta IZ et al. Myopathy, muscle atrophy and tongue lipid composition in MuSK myasthenia gravis. Acta Neurol Belg. 2015;115(3):361-5. https://doi.org/10.1007/s13760-014-0364-1 